\title{
ANALISIS PENERAPAN SAK ETAP (STANDAR AKUNTANSI KEUANGAN ENTITAS TANPA AKUNTABILITAS PUBLIK) DALAM PENYUSUNAN DAN PENYAJIAN LAPORAN KEUANGAN PADA PT CIPTA AGUNG LESTARI
}

\author{
Nurjannah Citradewi ${ }^{1}$ ) \\ ${ }^{1)}$ Program Studi Akuntasi, Fakultas Ekonomi Universitas Krisnadwipayana \\ Kampus Unkris Jatiwaringin \\ email: citra0112@gmail.com \\ Esti Damayanti ${ }^{2}$ ) \\ ${ }^{2)}$ Program Studi Akuntansi, Fakultas Ekonomi Universitas Krisnadwipayana \\ Kampus Unkris Jatiwaringin \\ email: estidamayanti1678@gmail.com
}

\begin{abstract}
SAK ETAP is an accounting standard set by IAI with the purpose of facilitating medium enterprises in preparing and presenting the financial statements to be more informative and relevant, so it will be interpretated by the external users, such as investors and creditors to providing financing for SME's. The purpose of this research is to determine the presentation of PT Cipta Agung Lestari financial statements by an entity's financial accounting standards without public accountability (SAK ETAP). This research used a description comparative method with secondary data sources and the results of this research indicate that the presentation of PT Cipta Agung Lestari financial statements are not yet complied with SAK ETAP, because the company has not applied adjustment journals in accounting cycle and has not presented statement of owner's equity, cash flow statement and notes to financial statement.
\end{abstract}

Keywords : Accounting cycle, Financial statement, SAK ETAP

\section{PENDAHULUAN}

Pada laporan keuangan terdapat informasi yang dapat menggambarkan keadaan perusahaan, akan tetapi sepenuhnya belum dapat digunakan, karena laporan keuangan tersebut harus dapat dianalisis dengan tepat. Pihak-pihak yang berkepentingan (interested party) harus dapat menginterpretasikan laporan keuangan dengan penilaian dan pemahaman yang sama. Oleh karena itu, suatu standar akuntansi sangat diperlukan untuk mengatur penyusunan dan penyajian laporan keuangan perusahaan.

Entitas yang tidak memiliki akuntabilitas publik yang signifikan dan menerbitkan laporan keuangan untuk tujuan umum yaitu pengguna dan pihak-pihak eksternal seperti investor dan kreditur harus mengacu dengan Standar Akuntansi Keuangan Entitas Tanpa Akuntabilitas Publik (SAK ETAP).Tujuan diterbitkannya SAK ETAP adalah untuk mempermudah perusahaan kecil dan menengah agar laporan keuangan dapat disusun dan disajikan secara akurat, terpercaya dan relevan. Harapan dengan diterbitkannya SAK ETAP, perusahaan kecil dan menengah bisa menyusun dan menyajikan laporan keuangan dengan mandiri, agar dapat diaudit dan mendapatkan opini/penilaian dari auditor, sehingga laporan keuangan dapat digunakan perusahaan untuk mendapatkan dana/modal untuk meningkatkan kegiatan peusahaannya. PT Cipta Agung Lestari adalah perusahaan menengah yang bergiat di aspek perdagangan dan impor aksesoris komputer. Dalam menyusun dan menyajikan laporan keuangannya, PT Cipta Agung Lestari harus sesuai dengan SAK ETAP karena PT Cipta Agung Lestari termasuk perusahaan menengah dan merupakan entitas yang tidak memiliki akuntanbilitas publik. Pencapaian serta besarnya potensi PT Cipta Agung Lestari ternyata tidak lantas menyebabkan perusahaan mampu meningkatkan performa dengan cepat terutama produk penjualannya terhadap masyarakat luas. Hal tersebut dikarenakan PT Cipta Agung Lestari mengalami kesulitannya yang paling utama adalah keterbatasan modal dan sulitnya mengakses sumber permodalan. Berdasarkan observasi dan wawancara pada PT Cipta Agung Lestari, perusahaan ini sudah berdiri selama 10 tahun dan mereka berencana untuk memajukan dan mengekspansi usahanya agar bisa bersaing dengan perusahaan 
pesaingnya. Dapat dilihat data penjualan PT Cipta Agung Lestari adalah

\begin{tabular}{cccc}
\multicolumn{5}{c}{ Tabel 1 } \\
\multicolumn{4}{c}{ Data Penjualan PT Cipta Agung Lestari } \\
\hline Tahun & & Total Penjualan & $\begin{array}{c}\text { Peningkatan } \\
(\%)\end{array}$ \\
\hline 2015 & $\operatorname{Rp}$ & $144.883 .887 .223,00$ \\
\hline 2016 & $\operatorname{Rp}$ & $149.482 .554 .541,00$ & $1,032 \%$ \\
\hline 2017 & $\operatorname{Rp}$ & $153.027 .933 .806,00$ & $1,024 \%$ \\
\hline Sumber: Data PT Cipta Agmmg Lestari (2018) &
\end{tabular}

Dengan penjualan yang terus meningkat PT Cipta Agung Lestari berencana untuk mengajukan penambahan kredit modal usaha ke bank. Untuk mengajukan kredit modal usaha, pihak bank memberikan persyaratan berupa laporan keuangan perusahaan yang harus mengacu dan sesuai SAK ETAP dengan tujuan untuk menilai kelayakan kredit dari PT Cipta Agung Lestari.

Dalam memenuhi persyaratan dari bank, PT Cipta Agung Lestari menyusun laporan keuangan untuk periode tahun 2017 harus mengacu dan sesuai dengan SAK ETAP, tetapi pengimplementasiannya belum sepenuhnya diterapkan perusahaan. Pada tahun 2017, laporan keuangan PT Cipta Agung Lestari hanya berupa laporan neraca dan laporan laba rugi, sedangkan laporan keuangan yang lengkap berdasarkan SAK ETAP adalah terdiri dari laporan neraca (posisi keuangan), laporan laba rugi, laporan arus kas, laporan perubahan ekuitas dan catatan atas laporan keuangan.

Selain untuk meningkatkan modal, permasalahan yang terdapat pada PT Cipta Agung Lestari adalah masih belum diterapkannya jurnal penyesuaian pada tahapan siklus akuntansi dalam pembuatan laporan keuangan, karena dalam kegiatan usahanya setiap transaksi yang berkaitan dengan biaya tidak dilakukan penyesuaian pada akhir tahunnya. Dengan demikian PT Cipta Agung Lestari harus menyusun laporan keuangannya berdasarkan acuan SAK ETAP yang berlaku.

\section{TINJAUAN PUSTAKA}

\section{Standar Akuntansi Keuangan Entitas Tanpa Akuntabilitas Publik}

Menurut Cahyono (2011), Indonesia memiliki standar akuntansi keuangan sendiri yang berlaku untuk kalangan umum di
Indonesia. Prinsip dan standar akuntansi yang digunakan secara umum di Indonesia adalah standar yang dikeluarkan oleh Ikatan Akuntan Indonesia (IAI). IAI merupakan suatu organisasi profesi akuntan yang ada di Indoensia. IAI berdiri pada tahun 1957, selain untuk mewadahi para akuntan, IAI mempunyai peran besar dalam dunia akuntansi di Indonesia.Peran yang dimaksud adalah sebagai penyusun standar akuntansi keuangan Indonesia. Standar akunatnsi tersebut merupakan aturan yang mengatur tentang pelaksanaan kegiatan akunatnsi di dunia perbisnisan Indonesia.

Menurut pendapat Ryan Ariefiansyah dan Misoyi Margu Utami (2013: 10), definisi SAK ETAP adalah:

"SAK ETAP adalah standar akuntansi untuk entitas yang memiliki skala kecil hingga menengah, misalnya UKM yang tidak memiliki akuntabilitas publik."

Standar Akuntansi Keuangan Entitas Tanpa Akuntabilitas Publik atau biasa disingkat SAK ETAP adalah standar akuntansi keuangan yang hanya diperuntukkan bagi entitas tanppa akuntabilitas publik. SAK ETAP disahkan pada tanggal 19 Mei 2009 di Jakarta. SAK ETAP terdiri dari 30 bab pembahasan dan disertai dengan daftar istilah di bagian paling akhir. SAK ETAP hanya dapat digunakan oleh entitas yang:

1. Tidak memilki akuntabilitas publik signifikan.

2. Menerbitkan laporan keuangan untuk tujuan umum (general purpose financial statement) bagi pengguna eksternal. Pengguna eksternal yang dimaksud adalah investor, kreditur dan lembaga pemberi peringkat kredit.

Entitas memiliki akuntabilitas publik

signifikan jika:

1. Entitas telah mengajukan pernyataan pendaftaran, atau dalam proses pengajuan pernyataan pendaftaran, pada otoritas pasar modal atau regulator lain untuk tujuan penerbitan efek di pasar modal, atau

2. Entitas menguasai atas aset dalam kapasitas sebagai fidusia untuk sekelompok besar masyarakat, sepeti bank, entitas asuransi, pialang dana atau pedagang efek.

Tujuan Penyusunan SAK ETAP

Menurut Dwi Martani (2012:37), Perusahaan dapat menggunakan SAK ETAP dikarenakan, yang pertama adalah karena PSAK terlalu kompleks untuk diterapkan 
terutama bagi perusahaan kecil dan menengah karena fair value memerlukan biaya yang banyak. Yang kedua adalah karena PSAK menggunakan principle based sehingga membutuhkan professional judgment dan yang ketiga adalah karena PSAK memerlukan dokumentasi dari IT yang kuat. Oleh sebab itu, perusahaan kecil dan menengah hanya bisa menggunakan SAK ETAP sebagai standar akuntansi keuangan mereka.

Dwi Martani (2012:39) menjelaskan bahwa penerapan PSAK umum yang mengacu pada IFRS lebih sulit dibandingkan dengan menerapkan SAK ETAP, hal ini dikarenakan SAK ETAP mudah dipraktikan untuk akuntansi yang digunakan saat ini. SAK ETAP dapat dengan bebas diterapkan oleh entitas tanpa akuntabilitas publik (ETAP), apabila entitas belum mempunyai rencana untuk mengembangkan bisnisnya dapat menjalankan standar keuangannya secara sederhana dan tidak membutuhkan pendanaan dari bank, maka entitas tidak memerlukan PSAK umum. SAK ETAP bisa digunakan oleh entitas yang memiliki akuntabilitas publik signifikan apabila otoritas berwenang sudah memberikannya izin regulasi.

\section{Penyajian Laporan Keuangan}

Menurut SAK ETAP (2016: 3 paragraf 6) penyampaian dan klasifikasi pos-pos pada laporan keuangan harus konsiten disetiap periodenya, kecuali:

1. Apabila terjadi perubahan yang signifikan atas kualitas operasi entitas atau adanya perubahan pengklasifikasian atau penyajian yang bertujuan untuk mengahasilkan penyajian yang lebih baik sesuai dengan karkateristik dalam pemilihan dan penerapan kebijakan akuntansi.

2. SAK ETAP memberikan syarat suatu perubahan penyajian.

Perihal penjelasan yang komperatif, dala SAK ETAP (2016: 3 paragraf 9) menyatakan bahwa Informasi dinyatakan lain apabila tidak diungkapkan secara komperatif dengan SAK ETAP (termasuk semua informasi yang terdapat dalam laporan keuangan khusunya catatan atas laporan keuangan). Entitas dapat memasukkan informasi yang komperatif secara naratif dan deskriptif jika pemahamannya relevan pada laporan keuangan di periode berjalan.

Dalam SAK ETAP (2016: 3 paragraf 16), setiap entitas harus merekognisi secara jelas pada setiap unsur-unsur laporan keuangannya termasuk catatan laporan aliran kas. Jika laporan keuangan termasuk ke dalam unsur dari laporan yang lainnya, maka harus dibedakan dari informasi lain yang ada pada laporan tersebut. Selain itu, informasi berikut ini dapat disajikan pada setiap halaman laporan keuangan.

1. Setiap nama entitas pelapor dan perubahan dengan nama tersebut terhitung sejak pelaporan pada periode terakhir;

2. Waktu dan periode yang dicakuo oleh laporan keuangan, hanya memilih mana yang lebih tepat untuk setiap unsur laporan keuangannya;

3. Mata uang pada setiap pelaporannya;

4. Pembulatan angka yang digunakan dalam setiap penyajian laporan keuangan.

\section{Pengakuan Unsur Laporan Keuangan} Menurut SAK ETAP (2016: 2 paragraf 24), Pengakuan dari setiap unsur laporan keuangan adalah merupakan proses dibentuknya suatu pos dalam laporan neraca atau laporan laba rugi yang memenuhi definisi dari suatu unsur dan harus memenuhi kriteria sebagai berikut:

1. Adanya kemungkinan bahwa manfaat ekonomi yang berkaitan dengan pos-pos tersebut akan bergerak dari atau ke dalam entitas; dan

2. Pos-pos tersebut memiliki nilai atau biaya yang dapat diukur dengan andal dan akurat.

Berdasarkan penjelasan pengakuan unsur laporan keuangan dalam SAK ETAP (2016) adalah sebagai berikut:

1. Pengakuan aset

Aset akan diakui dalam neraca apabila perkiraan masa manfaat ekonominya di masa mendatang akan mengalir ke entitas dan aset tersebut memilki nilai atau biaya yang bisa diukur dengan andal dan akurat. Tetapi aset tidak akan diakui dalam neraca jika pengeluarannya telah terjadi dan masa manfaat ekonominya dilihat tidak mungkin mengalir ke dalam entitas setelah pelaporan di periode berjalan. Adapun alternatifnya, transaksi tersebut mengakibatkan pengakuan beban pada laporan laba rugi.

2. Pengakuan kewajiban

Kewajiban akan diakui dalam laporan neraca apabila perkiraan sumber daya yang mempunyai manfaat ekonomi akan 
dilakukan untuk menyelesaikan kewajiban di masa sekarang dan jumlah yang harus dibayarkan dapat diukur dengan andal dan akurat.

3. Pengakuan penghasilan

Pengakuan penghasilan adalah merupakan konsekuensi langsung yang timbul dari pengakuan aset dan kewajiban. Penghasilan dapat diakui dalam laporan laba rugi apabila terdapat kenaikan manfaat ekonominya di masa mendatang yang berkaitan dengan meningkatnya aset atau menurunnya kewajiban yang telah terjadi dan dapat diukur secara andal dan akurat.

\section{Pengakuan Laporan Keuangan}

Pada SAK ETAP (2016: 2 paragraf 30) mendefinisikan bahwa pengukuran adalah proses penetapan nilai uang yang akan digunakan entitas untuk mengukur suatu aset, kewajiban, penghasilan serta beban dalam pada laporan keuangan. Dasar-dasar pengukuran yang umum adalah sebagai berikut:

1. Biaya historis

Aset merupakan jumlah nilai kas atau setara kas yang dibayarkan atau nilai wajar dari transaksi pembayaran yang diberikan untuk memperolehaset pada saat perolehan. Kemudian kewajiban dicatat sebesar kas atau setara kas yang diterima atau sebesar nilai wajar dari aset non kas yang diterima sebagai media penukar dari kewajiban pada saat transaksi kewajiban transaksi.

2. Nilai wajar

Nilai wajar merupakan jumlah nilai yang digunakan untuk menukar suatu aset atau untuk membayarkan suatu kewajiban antara pihak-pihak yang memiliki keinginan dan pengetahuan yang layak pada suatu transaksi dengan wajar.

\section{Informasi yang Disajikan Dalam Neraca}

Laporan neraca mempresentasikan aset, kewajiban dan ekuitas suatu entitas pada tanggal tertentu biasanya pada akhir periode pelaporan. Komponen laporan neraca minimal harus mencakup pos-pos sebagai berikut: a.)kas dan setar kas, b.)piutang usaha dan piutang lainnya, c.)persediaan, d.)properti investasi, e.)aset tetap, f.)aset tidak berwujud, g.)hutang usaha dan hutang lainnya, h.)aset dan kewajiban pajak, i.)kewajiban diestimasi, j.)ekuitas.
Dalam rangka pemahaman terhadap posisi keuangan, entitas harus relevan dalam menyajikan pos, judul dan sub bab jumlah lainnya ke dalam neraca. SAK ETAP tidak mengharuskan format atau urutan-urutan terhadap pos-pos yang akan disajikan dalam laporan keuangan.

\section{Informasi yang Disajikan di Laporan Laba Rugi}

Pada laporan laba rugi harus memasukkan semua pos-pos pendapatan dan beban yang diakui dalam satu periode kecuali disyaratkan lain oleh SAK ETAP. Berikurt adalah pos-pos yang minimal harus dicakup laporan laba rugi: a.)Pendapatan, b.)Beban keuangan, c.)Bagian laba atau rugi investasi yang menggunakan moteode ekuitas, d.)Beban pajak, e.)Laba atau rugi neto.

Untuk memahami kinerja keuangan entitas, laporan laba rugi wajib menyajikan pos, judul dan sub jumlah lainnya tersebut secara relevan dan andal. Entitas tidak diperbolehkan mengungkapkan atau menyajikan pos-pos pendapatan dana beban sebagai pos luar biasa pada laporan laba rugi dan catatan atas laporan keuangan.

Informasi yang Disajikan di Laporan Perubahan Ekuitas

Dalam laporan ekuitas, entitas harus menyajikan laba atau rugi dalam suatu periode, serta pada periode tersebut pos pendapatan dan beban diakui secara langsung dalam ekuitas tersebut, perubahan kebijakan akuntansi dan koreksi kesalahan yang diakui sangat berpengaruh pada periode tersebut dan jumlah investasi dan deviden yang didistribusikan kepada pemilik ekuitas selama periode berjalan tersebut. Entitas harus menyajikan laporan perubahan ekuitas yang menggambarkan:

a) Laba atau rugi untuk suatu periode;

b) Pos pendapatan dan beban yang diakui langsung dalam ekuitas;

c) Untuk setiap unsur-unsur ekuitas, pengaruh perubahan kebijakan akuntansi serta koreksi kesalahan yang diakui.

d) Untuk setiap unsur-unsur ekuitas, suatu rekonsiliasi antara jumlah pencatatan awal dan pada akhir periode, diungkapkan secara terpisah dari perubahan-perubahan yang berasal:

(i) Laba atau ruginya entitas; 
(ii) Jumlah pendapatan dan beban yang diakui secara langsung pada ekuitas;

(iii) Jumlah nilai investasi, deviden dan distribusi ke setiap pemilik

(iv) ekuitas yang menunjukkan secara terpisah antara modal saham, transaksi saham treasury dan juga deviden serta distribusi lainnya ke pemilik ekuitas.

Informasi yang Disajikan Dalam Laporan Arus Kas

Laporan arus kas harus menyajikan informasi perubahan seacra historis atas kas dan setara kas entitas yang menggambarkan perubahan secara terpisah selama satu periode dari aktivitas aliran kas operasi, investasi dan pendanaan. Entitas harus menyajikan laporan arus kas dari mulai mengklasifikasikan berdasarkan aktivitas operasi, aktivitas investasi dan aktivitas pendanaan dalam melaporkan arus kas pada suatu periode tertentu.

\section{Informasi yang Disajikan Dalam Catatan Atas Laporan Keuangan}

Pada catatan atas laporan keuangan harus menyampaikan penjelasan secara naratif atas rincian-rincian jumlah yang akan disajikan pada laporan keuangan dan menginformasikan pos-pos yang tidah sesuai dengan kriteria pengakuan dalam laporan keuangan. Pada catatan atas laporan keuangan harus:

a) Menyajikan informasi mengenai dasar penyusunan laporan keuangan dan kebijakan akuntansi tertentu yang akan digunakan sesuai dengan SAK ETAP paragraf 8.5 dan 8.6;

b) Mengungkapkan informasi yang menjadi syarat dalam SAK ETAP tetapi tidak perlu disajikan dalam laporan keuangan, dan

c) Memberikan informasi tambahan yang ada dalam penyajian laporan keuangan, tetapi relevan untuk dapat memahami suatu laporan keuangan.

\section{METODE PENELITIAN}

Melalui pendekatan kualitatif dapat lebih menekankan pada perolehan informasi secara langsung dari objek penelitian dan tidak ada batasan antara peneliti dengan objek yang akan diteliti. Kemudian teknik pengumpulan data yang digunakan pada penelitian ini adalah menggunakan studi lapangan (field research).
Adapun cara-cara studi lapangan yang dilakukan oleh peneliti adalah sebagai berikut:

1. Observasi

Observasi adalah merupakan tahap pengumpulan data dengan cara mengadakan pengamatan secara langsung kepada PT Cipta Agung Lestari terhadap penerapan SAK ETAP.

Dalam penelitian ini peneliti memakai oservasi non perilaku dengan menganalisis catatan berupa pengumpulan data yang berasal dari catatan data masa kini dan catatan data historis. Penulis melakukan pengamatan dengan cara melihat secara langsung proses dari awal terjadinya transaksi kemudian melakukan pencatatan yang dilakukan oleh pihak yang terkait dengan penyusunan laporan keuangan yang bekerja di PT Cipta Agung Lestari.

\section{Wawancara (Interview)}

Wawancara merupakan cara komunikasi dua arah untuk mendapatkan data-data yang dibutuhkan dari subjek penelitian. Peeliti melakukan tanya jawab secara langsung baik formal maupun nnformal dengan pihak-pihak yang bersangkutan dalam setiap pokok bahasan yang akan dibahas dalam penelitian ini, yaitu mengenai penerapan SAK ETAP dalam pencatatan keuangan perusahaan.

3. Dokumentasi

Pada bagian dokumentasi ini dilakukan untuk mendapatkan bukti-bukti penelitian yang keasliannya dapat dipertanggungjawabkan. Peneliti melakukan dokumentasi pada PT Cipta Agung Lestari dengan melakukan pengamatan terhadap sistem akuntansi dan penyusunan laporan keuangan yang berdasarkan pada SAK ETAP yang terdiri dari laporan keuangan yang lengkap. Teknik dokumentasi dilakukan dengan meng-copy dokumen atau catatan laporan keuangan dari PT Cipta Agung Lestari.

\section{Metode Analisis Data}

Analisis yang digunakan oleh peneliti adalah menggunakan metode:

\section{Deskriptif}

Metode yang dilakukan peneliti mulai dari pengumpulan data kemudian disusun berdasarkan urutan, lalu diinterpretasikan dan terakhir peneliti melakukan analisis sehingga dapat memberikan keterangan dan rincian yang lengkap untuk menyelesaikan masalah yang dihadapi.

2.Komparatif 
Metode komparatif adalah metode analisis yang dilakukan peneliti dengan membandingkan antara teori-teori akuntansi dengan praktik yang terjadi di dalam perusahaan dan kemudian menarik kesimpulan dari hasil perbandingan tersebut.

Aktivitas dalam menganalisis yaitu meliputi:

1. Reduksi data (data reduction)

Data yang berasal dari lapangan baik berupa wawancara, observasi maupun dokumendokumen pendukung untuk menganalisis penerapan SAK ETAP. Pemilihan dilakukan berdasarkan dari pertanyaan pada saat wawancara, dan hasil dari observasi maupun poin-poin pada dokumen yang berhubungan dengan permasalahan yang diteliti.

2.Sajian data (data display)

Setelah peneliti melakukan reduksi data, hasil dari reduksi yang menampilkan data-data yang berhubungan dan berkaitan serta menjawab permasalahan yang diteliti. Dengan disertainya pemikiran dan analisis dari peliti berhubungan dengan data yang diperoleh, dan penyajian penelitian ini bersifat naratif.

3.Pengambilan kesimpulan (conclusion drawing).

Pada aktivitas ini peneliti menemukan bentuk pola atau ketertarikan antara analisis yang dilakukan dengan data-data yang didapatkan sehingga bentuk pola tersebut memudahkan peneliti untuk menarik kesimpulan.

Peneliti bermaksud untuk menggambarkan keadaan sebenarnya yang ada di lapangan kemudian mengadakan analisis data-data yang sudah diperoleh. Tahapan-tahapan yang peneliti lakukan setelah mendapatkan data kemudian menggambarkan lalu menerapkan laporan keuangan berbasis SAK ETAP pada PT Cipta Agung Lestari terdiri atas beberapa tahap, yaitu :

1. Melakukan pengumpulan data pada PT Cipta Agung Lestari.

2. Mengelompokkan data dan mengurutkan data pada siklus akuntansi, seperti akun, jurnal umum kemudian di-posting ke buku besar, masuk ke neraca saldo, melakukan jurnal penyesuaian dan jurnal penutup serta pembuatan laporan keuangan.

3. Menganalisa bagaimana penerapan jurnal penyesuaian pada transaksi PT Cipta Agung Lestari.

4. Menganalisa bagaimana kondisi penyusunan laporan keuangan PT Cipta Agung Lestari yang digunakan saat ini.
5. Menerapkan laporan keuangan PT Cipta Agung Lestari dengan laporan keuangan yang secara lengkap berdasarkan SAK ETAP, seperti: laporan neraca, laporan laba rugi, laporan perubahan ekuitas, laporan arus kas dan catatan atas laporan keuangan.

6. Menarik kesimpulan dan memberikan saran bagi perkembangan dan kemajuan perusahaan.

\section{HASIL DAN PEMBAHASAN}

Analisis Kesesuaian Laporan Laba Rugi PT Cipta Agung Lestari terhadap SAK ETAP

Sama halnya dengan neraca, laporan laba lugi dan laporan perubahan ekuitas juga harus dengan pengakuan metode akrual. Laporan laba rugi yang disusun dan disajikan bertujuan untuk memberikan gambaran atas kinerja perusahaan pada suatu periode yaitu selama satu tahun. Laba ataupun rugi yang didapatkan oleh perusahaan sangat mempengaruhi saldo laba dalam neraca dan bersamaan dengan setiap perubahan unsurunsur ekuitas lainnya, maka selanjutnya harus menyusun laporan laba rugi. Ada beberapa pos-pos yang harus dijabarkan oleh perusahaan saat menyusun laporan laba rugi, yaitu pendapatan, beban keuangan, bagian laba atau rugi dari investasi yang memakai metode ekuitas, beban pajak, serta jumlah nilai investasi, deviden dan distribusi lainnya kepada pemilik ekuitas. Faktanya yang terjadi pada PT Cipta Agung Lestari adalah tidak semua unsur-unsur tersebut tersedia pada laporan keuangan. Pada laporan yang dibuat PT Cipta Agung Lestari ini, pos-pos yang wajib ada hanyalah pos pendapatan, beban keuangan, laba (rugi) neto, serta jumlah akhir laba atau ruginya usaha. Tidak adanya pos wajib lainnya dikarenakan memang tidak adanya investasi yang menggunakan metode ekuitas oleh PT Cipta Agung Lestari dan tidak terdapat dilakukannya distribusi, koreksi ataupun perubahan-perubahan kebijakan yang bisa mempengaruhi ekuitas. 
Tabel 2

Checklist Pos Laporan Laba Rugi Terhadap SAK ETAP

\begin{tabular}{lcl}
\hline \multicolumn{1}{c}{ Pos } & Ada/Tidak & \multicolumn{1}{c}{ Keterangan } \\
\hline Pendapatan & Ada & - \\
\hline Beban Keuangan & Ada & - \\
\hline $\begin{array}{l}\text { Bagian laba atau rugi dari } \\
\text { investasi yang } \\
\text { menggunakan metode } \\
\text { ekuitas }\end{array}$ & Tidak & $\begin{array}{l}\text { PT Cipta Agung Lestari tidak } \\
\text { memiliki transaksi dengan laba rugi } \\
\text { dari investasi dengan menggunakan } \\
\text { metode ekuitas. }\end{array}$ \\
\hline Beban pajak & Tidak & $\begin{array}{l}\text { PT Cipta Agung Lestari belum } \\
\text { menerapkan pembayaran pajak pada } \\
\text { tahun 2017. }\end{array}$ \\
\hline Laba atau rugi neto & Ada & - \\
\hline \multicolumn{1}{c}{ Sumber : Data diolah penulis (2018) } &
\end{tabular}

1. Pendapatan

Berdasarkan SAK ETAP menjelaskan bahwa pengakuan penghasilan adalah merupakan akibat langsung yang timbul dari pengakuan set dan kewajiban yang merupakan unsur-unsur dari laporan neraca Penghasilan/pendapatan yang diakui pada laporan laba rugi adalah jika terdapat kenaikan dari manfaat ekonomi di masa yang akan datang dan berhubungan dengan peningkatan aset ataupun penurunan kewajiban yang sudah terjadi dan harus dapat diukur secara akurat. Rincian pendapatan PT Cipta Agung Lestari adalah sebagai berikut:

Tabel 3

\begin{tabular}{lr}
\multicolumn{2}{c}{ Tabel 3 } \\
Pos Pendapatan Pada Laporan Laba Rugi \\
\hline Pendapatan \\
\\
- Pendapatan Penjualan & 153.005 .492 .006 \\
- Pendapatan Service & 22.441 .800 \\
- Pendapatan Bunga Bank & 39.202 .804 \\
- Pendapatan Lain-lain & 34.538 .946 \\
Jumlah Pendapatan & 153.101 .675 .556
\end{tabular}

Sumber : Data diolah penulis (2018)

2. Beban

Pada beban seharusnya dikelompokkan lebih lanjut atsa dasar sifat dan fungsi beban. Akan tetapi, pada SAK ETAP disebutkan bahwa perusahaan yang mengelompokkan beban-beban berdasarkan fungsi pengungkapan informasi tambahan berdasarkan sifat beban, yaitu penyusutan, beban-beban amortisasi dan juga imbalan kerja. PT Cipta Agung Lestari mengelompokkan beban-beban berdasrkan fungsifungsinya dan kemudian memberikan informasi yang lebih lanjut tentang sifat-sifat beban melalui subkatergori pada masing-masing beban menurut fungsinya masing-masing. Rincian beban PT Cipta Agung Lestari adalah sebagai berikut:

Tabel 4

\begin{tabular}{lr}
\multicolumn{2}{c}{ Pos Beban Pada Laporan Laba Rugi } \\
\hline Beban Usaha & Jumlah (Rp) \\
Beban Pokok Penjualan & 135.438 .328 .565 \\
Beban Umum dan Administrasi & 5.210 .456 .410 \\
Beban Keuangan Bank & 3.098 .097 .751 \\
Beban Operasi Lain-lain & 72.497 .969 \\
\cline { 2 - 2 } Jumlah Beban Usaha & 143.819 .380 .695 \\
& \\
\hline Sumber: Data diolah penulis (2018) &
\end{tabular}

Penyajian Laporan Keuangan PT Cipta Agung Lestari Berdasarkan SAK ETAP

Berdasarkan SAK ETAP ketentuan yang digunakan perusahaan wajib menyajikan aset lancar dan tidak lancar, kewajiban jangka pendek dan jangka panjang begitu juga dengan laporan keuangan bedasarkan SAK ETAP meliputi laporan neraca, laporan laba rugi, laporan arus kas, laporan perubahan ekuitas dan catatan atas laporan keuangan. Berikut laporan keuangan PT Cipta Agung Lestari per Desember 2017 yang disusun oleh peneliti dapat adalah sebagai berikut :

1. Laporan Neraca

Dalam menyusun dan menyajikan laporan keuangan seperti laporan neraca, perusahaan bisa menggunakan beberapa bentuk yang sesuai dengan tujuan dan kebutuhan yang diinginkan sesuai dengan aturan yang berlaku, dalam arti penyusunan laporan neraca didasarkan pada bentuk yang telah ditetapkan untuk tujuan pihak luar perusahaan. Berikut penyajian laporan neraca PT Cipta Agung Lestari setelah diolah dan kemudian disusun berdasarkan SAK ETAP, sebagai berikut: 


\begin{tabular}{|c|c|}
\hline \multicolumn{2}{|c|}{$\begin{array}{cc} & \text { Tabel } 5 \\
\text { Laporan Neraca Berdasarkan SAK ETAP }\end{array}$} \\
\hline Laporan Neraca & $\begin{array}{l}\text { STARI } \\
2017\end{array}$ \\
\hline \multicolumn{2}{|l|}{ Aset } \\
\hline \multicolumn{2}{|l|}{ Aset Lancar } \\
\hline Kas dan Setara Kas & 1.115.677.667 \\
\hline Bank & 2.735.178.277 \\
\hline Piutang Usaha & 37.104 .110 .958 \\
\hline Persediaan & 39.779 .254 .273 \\
\hline Sewa Dibayar Dimuka & 371.703 .683 \\
\hline Aset Lain-lain & 770.960 .000 \\
\hline Total Aset Lancar & 81.876 .884 .857 \\
\hline \multicolumn{2}{|l|}{ Aset Tidak Lancar } \\
\hline Tanah & 2.500 .000 .000 \\
\hline Bangunan & 20.900 .122 .845 \\
\hline Akm Penyusutan Bangunan & (7.676.059.995) \\
\hline Kendaraan & 1.257 .000 .000 \\
\hline Akm Penyusutan Kendaraan & (969.604.167) \\
\hline Peralatan Kantor & 228.776 .550 \\
\hline Akm Penyusutan Peralatan & $(228.776 .550)$ \\
\hline Total Aset Tidak Lancar & 16.011 .458 .683 \\
\hline Total Aset & 97.888.343.541 \\
\hline \multicolumn{2}{|l|}{ Kewajiban } \\
\hline \multicolumn{2}{|l|}{ Kewajiban Jangka Pendek } \\
\hline Hutang Dagang & 576.340 .700 \\
\hline Hutang Pajak & 1.160 .286 .858 \\
\hline Hutang Lain-lain & 249.297 .278 \\
\hline Total Kewajiban Jangka Pendek & 1.985 .924 .835 \\
\hline \multicolumn{2}{|l|}{ Kewajiban Jangka Panjang } \\
\hline Hutang Bank & 28.141 .000 .000 \\
\hline Total Kewajiban Jangka Panjang & 28.141 .000 .000 \\
\hline \multicolumn{2}{|l|}{ Ekuitas } \\
\hline Modal Sendiri & 550.000 .000 \\
\hline Saldo Laba & 59.089 .410 .704 \\
\hline Laba / rugi tahun berjalan 2017 & 8.122 .008 .002 \\
\hline Total Ekuitas & 67.761 .418 .705 \\
\hline Total Kewajiban & 97.888.343.541 \\
\hline
\end{tabular}

a. Aset Lancar

PT Cipta Agung Lestari memiliki aset lancer untuk menjalankan usahanya sebesar Rp81.876.884.857 yang diperoleh dari kas dan setara kas sebesar Rp1.115.677.667, saldo bank sebesar Rp2.735.178.277, memiliki piutang dagang sebesar Rp37.104.110.958, kemudian adanya persediaan Rp39.779.254.273, sewa dibayar dimuka sebesar Rp 371.703.683 dan aset lain-lain sebesar Rp770.960.000 pada akhir bulan Desember 2017.

b. Aset Tetap

Total aset tetap PT Cipta Agung Lestari adalah Rp16.011.458.683 yang diperoleh dari total aset yang dimiliki dilihat dari nilai perolehannya kemudian dikurangi dengan akumulasi penyusutan, setelah data diolah terdapat pemisahan aset tetap PT Cipta Agung Lestari berupa tanah, bangunan, peralatan kantor karena sesuai dengan SAK ETAP bahwa tanah harus berdiri sendiri tidak boleh dijadikan satu akun dengan aset tetap yang lain karena tanah tidak dapat disusutkan nilainya. c. Kewajiban Jangka Pendek

Kewajiban lancar PT Cipta Agung Lestari sebesar Rp 825.637.978 yang terdiri dari hutang dagang sebesar Rp576.340.700, hutang pajak sebesar Rp1.160.286.858 dan hutang lain-lain yaitu hutang bunga bank Rp249.297.278.

d. Kewajiban Jangka Panjang PT Cipta Agung Lestari memiliki hutang jangka panjang satu tahun pada Bank sebesar Rp28.141.000.000, tetapi pada laporan neraca sebelum disesuaikan dengan SAK ETAP dicatat sebagai hutang jangka pendek. Hutang bank tersebut memiliki jangka waktu satu tahun.

e. Ekuitas

Jumlah ekuitas PT Cipta Agung Lestari sebesar Rp 67.211.418.706 terdiri dari modal sendiri, laba ditahan dan laba berjalan tahun 2017.

2. Laporan Laba Rugi Berikut laporan laba rugi PT Cipta Agung Lestari yang sudah sesuai dengan SAK ETAP adalah sebagai berikut:

\begin{tabular}{|c|c|}
\hline \multicolumn{2}{|c|}{$\begin{array}{l}\text { PT CIPTA AGUNG LESTARI } \\
\text { Laporan Laba Rugi } \\
\text { Periode } 31 \text { Desember } 2017 \\
\end{array}$} \\
\hline Pendapatan: & \\
\hline Pendapatan Penjualan & 153.027.933.806 \\
\hline Jumlah Pendapatan & 153.027 .933 .806 \\
\hline \multicolumn{2}{|l|}{ Harga Pokok Penjualan: } \\
\hline HPP Persediaan & $(135.438 .328 .565)$ \\
\hline Jumlah HPP Persediaan & $(135.438 .328 .565)$ \\
\hline Jumlah Laba Kotor & 17.589 .605 .241 \\
\hline \multicolumn{2}{|l|}{ Pendapatan (Beban) Operasi Lain-lain } \\
\hline Pendapatan Bunga Bank & 39.202 .804 \\
\hline Pendapatan Lain-lain & 34.538 .946 \\
\hline Beban Umum dan Administrasi & $(5.210 .456 .410)$ \\
\hline Beban Keuangan Bank & $(3.098 .097 .751)$ \\
\hline Beban Operasi Lain-lain & $(72.497 .969)$ \\
\hline Jumlah Pendapatan (Beban) Lain-lain & $(8.307 .310 .380)$ \\
\hline Laba (Rugi) Sebelum Pajak & 9.282 .294 .861 \\
\hline Taksiran Pajak & 1.160 .286 .858 \\
\hline Laba (Rugi) Setelah Pajak & 8.122 .008 .003 \\
\hline
\end{tabular}

Berdasarkan tabel diatas bahwa pos-pos pada laporan laba rugi dapat diuraikan sebagai berikut:
a. Pendapatan
Pendapatan PT Cipta Agung Lestari terdiri dari pendapatan penjualan dan pendapatan service yang berjumlah 
Rp153.027.933.806, pendapatan bunga bank sebesar Rp39.202.804 dan pendapatan lain-lain sebesar Rp34.538.946.

b. Beban

Total beban pada PT Cipta Agung Lestari sebesar Rp8.307.310.380 terdiri dari beban-beban umum dan administrasi, beban dari keuangan bank, beban operasi alin-lain, ditambah jumlah laba berjalan tahun ini. Setelah penyusunan laporan laba rugi menurut SAK ETAP diperoleh beban pajak Rp1.160.286.858 karena PT Cipta Agung Lestari wajib membayarkan pajak.

3. Laporan Perubahan Ekuitas

Persyaratan yang diatur oleh SAK ETAP untuk menyajikan perubahanperubahan pada ekuitas entitas dalam satu periode yang terjadi pada laporan laba rugi dan saldo serta laporan perubahan ekuitas. Berikut laporan perubahan ekuitas PT Cipta Agung Lestari yang sudah diteliti berdasarkan pada SAK ETAP adalah sebagai berikut:

Tabel 7

Laporan Perubahan Ekuitas Berdasarkan SAK ETAP PT CIPTA AGUNG LESTARI

Laporan Perubahan Ekuitas Periode 31 Desember 2017

\begin{tabular}{lr}
\hline Modal saham & 550.000 .000 \\
Saldo laba (Januari - Desember) & 59.089 .410 .704 \\
\cline { 2 - 2 } Modal per 31 Desember 2016 & 59.639 .410 .704 \\
Ditambah & \\
$\quad$ Saldo laba (Januari - Desember) & 8.122 .008 .003 \\
Dikurangi & \\
Prive (Januari - Desember) & -
\end{tabular}

$$
\begin{aligned}
& \text { Modal per } 31 \text { Desember } 2017 \quad 67.761 .418 .707 \\
& \text { Sumber : Data diolah penulis (2018) }
\end{aligned}
$$

Laporan perubahan ekuitas PT Cipta Agung Lestari mencantumkan setiap adanya perubahan-perubahan pada ekuitas/modal pemilik dalam suatu periode tertentu. Dari data diatas dapat diperoleh modal awal PT Cipta Agung Lestari sebesar Rp550.000.000 ditambah dengan saldo laba per Desember 2016 sebesar Rp59.089.410.704 kemudian ditambah dengan saldo laba tahun berjalan setelah pajak 2017 sebesar Rp8.122.008.003 diperoleh modal akhir sebesar Rp67.761.418.707. Laporan perubahan ekuitas adalah merupakan salah satu bentuk laporan yang sewajibnya dibuat oleh perusahaan dalam jangka waktu tertentu dan sesuai dengan SAK ETAP, tetapi PT Cipta Agung Lestari tidak membuat laporan perubahan ekuitas.

4. Laporan Arus Kas

Secara historis, laporan arus kas bisa memberikan informasi mengenai kan dan setara kas, transaksi mengenai pendanaan, ada atau tidaknya kenaikan dan penurunan kas bersih dari aktivitas pendanaan, operasi dan investasi pada periode tertentu. PT Cipta Agung Lestari tidak membuat ars kas padahal arus kas termasuk laporan keuangan yang harus disajikan menurut SAK ETAP, karena laporan arus kas dapat memberi gambaran perputaran kas secara jelas dari mana saja penerimaan dan pengeluaran kas diperoleh. Berikut adalah laporan arus kas sesudah SAK ETAP:

\begin{tabular}{|c|c|}
\hline $\begin{array}{l}\text { ARUS KAS DARI AKTIVITAS OPERASI } \\
\text { Laba (rugi) bersih tahun berjalan }\end{array}$ & 9.282 .294 .860 \\
\hline \multicolumn{2}{|l|}{$\begin{array}{l}\text { Penyesuaian untuk merekonsiliasi Laba (rugi) tahun } \\
\text { berjalan menjadi kas yang digunakan untuk aktivitas } \\
\text { operasi }\end{array}$} \\
\hline Penyusutan & 1.593 .612 .393 \\
\hline Laba (rugi) tahun berjalan setelah penyesuaian & 10.875 .907 .253 \\
\hline \multicolumn{2}{|l|}{ Penurunan (kenaikan) pada: } \\
\hline Piutang usaha & $(3.175 .714 .833)$ \\
\hline Persediaan & $(5.604 .110 .964)$ \\
\hline Piutang lain-lain & 19.668 .800 \\
\hline Beban dibayar dimuka & 109.691 .567 \\
\hline Aset lain-lain & $(2.240 .000)$ \\
\hline \multicolumn{2}{|l|}{ Kenaikan (Penurunan) pada: } \\
\hline Hutang usaha & $(1.072 .054 .225)$ \\
\hline Hutang lain-lain & 67.299 .944 \\
\hline Kas bersih digunakan untuk aktivitas operasi & $(9.657 .459 .711)$ \\
\hline \multicolumn{2}{|l|}{ Arus kas dari aktivitas investasi } \\
\hline \multicolumn{2}{|l|}{ Penurunan (kenaikan) pada: } \\
\hline Penambahan aset tetap & $(8.038 .803 .000)$ \\
\hline Kas bersih digunakan untuk aktivitas operasi & $(8.038 .803 .000)$ \\
\hline \multicolumn{2}{|l|}{ Arus kas dari aktivitas pendanaan pada } \\
\hline Peningkatan (penurunan) hutang bank & 4.871 .000 .000 \\
\hline Jumlah arus kas dari aktivitas pendanaan & 4.871 .000 .000 \\
\hline Kenaikan (penurunan) bersih kas dan setara kas & $(1.949 .355 .458)$ \\
\hline Kas dan setara kas awal tahun & 5.800 .211 .402 \\
\hline Kas dan setara kas akhir tahun & 3.850 .855 .944 \\
\hline
\end{tabular}

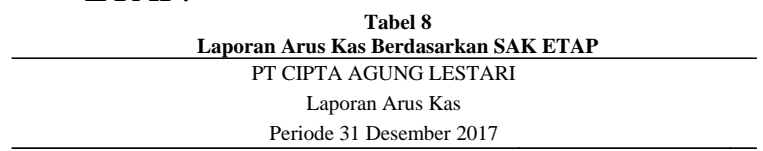

5. Catatan Atas Laporan Keuangan Yang terakhir, laporan keuangan berdasrkan SAK ETAP yaitu catatan atas laporan keuangan yang biasa 
disebut CALK. PT Cipta Agung Lestari juga tidak membuat CALK dalam laporan keuangannya. Komponenkomponen yang terdapat pada CALK adalah sebagai berikut:

a. Informasi Umum

1) Pendirian

PT Cipta Agung Lestari didirikan di Jakarta pada tahun 2008, perusahaan ini bergerak di bidang perdagangan aksesoris komputer. Perusahaan beralamat atau berdomisili di Gedung Pusat Harco Mangga Dua Lantai 3 No. 97, Jalan Mangga Dua Raya, Jakarta Pusat 10730.

2) Perizinan

Dalam perizinan PT Cipta Agung Lestari didirikan berdasarkan dengan akte Nomor 112 tanggal 15 Agustus 2008, dibuat dihadapan Notaris Titiek Irawati Sugianto, SH di Jakarta. Akte tersebut sudah mendapatkan pengesahan dari Kementrian Hukum dan HAM RI melalui surat keputusan Nomor AHU73124.H.01.01 Tahun 2008 tanggal 14 Oktober 2008. Akte perusahaan sudah mengalami perubahan beberapa dengan perubahan terakhir Akte Nomor 01 tanggal 13 November 2015, dibuat dihadapan Notaris Ruhhidayadi, SH., MH. Akta tersebut sudah mendapatkan pengesahan dari Kementrian Hukum dan HAM RI melalui surat keputusan Nomor AHU3583507.AH.01.11 Tahun 2015 tanggal 24 November, tentang pernyataan keputusan rapat.

b. Kebijakan Akuntansi

1) Dasar-Dasar Penyusunan Laporan Keuangan

Laporan arus kas merupakan laporan keuangan yang tidak menggunakan konsep harga perolehan serta memakai dasar akrual (accrual basis). Harga perolehan menjadi acuan untuk pengukurannya, dikecualikan pada akun-akun tertentu saja yang disajikan berdasarkan pada pengukuran lainnya dan diuraikan pada masing-masing kebijakan akuntansinya. Laporan keuangan ini menggunakan mata uang Rupiah kecuali dinyatakan lain. Periode pembukuan perusahaan dimulai dari tanggal 01 Januari sama 31 Desember pada setiap tahunnya.

2) Kas dan Setara Kas

Pada kas dan setara kas terdiri dari kas, simpanan yang dalam jangka pendek dapat dicairkan dan investasi likuid jangka pendek dengan jangka jatuh tempo dalam waktu kurang dari tiga bulan dan setelah dikurangi dengan overdraft. Overdraft merupakan bagian dari akun pinjaman jangka pendek dalam laporan neraca.

3) Piutang Usaha

Piutang usaha dapat disajikan dari jumlah niali bersih sesudah dikurangi oleh penyisihan piutang ragu-ragu yang sudah didasari atas penilaian secara kolektibiltas saldo piutang. Pada piutang yang dipastikan sudah tidak dapat tertagih harus dihapuskan.

4) Persediaan

Persediaan dapat dinyatakan sebagai biaya atau nilai realisasi bersih mana yang menunjukkan paling rendah. Penilaian biaya dapat ditentukan berdasarkan metode FIFO yaitu first in first out. Penyisihan pada persediaan yang slow moving ataupun rusak ditentukan pada estimasi penggunaan serta penjualan dari setiap jenis persediaan pada masa mendatang.

5) Aset Tetap

Pada aset tetap dibukukan dan dinilai berdasrkan harga perolehan yang sudah dikurangi akumulasi penyusutan. Pada tanah tidak dilakukan penyusutan. Penyusutan dihitung memakai metode garis lurus (straight line method).

6) Pendapatan dan Beban-Beban Pada pendapatan merupakan hasil dari penjualan barang. Dapat diakui sebagai pendapatan apabila:

1) Penjualan Barang 
Penjualan barang diakui ketika perusahaan sudah mengirimkan barang pesananan kepada pelanggan, kemudian barang sudah diterima pelanggan dan sudah memastikan bahwa piutang yang timbul dari penjualan barang secara kredit dapat ditagih sesuai dengan perjanjian.

2) Beban

Pada beban, akan diakui pada saat terjadi dan memakai dasar-dasar akrual.

7) Hutang Usaha

Pembelian barang dagang yang diakui sebagai hutang usaha apabila dibeli secara kredit. Tempo pembayaran hutang disesuaikan berdasarkan pada perjanjian antara perusahaan dan pemasok.

8) Ekuitas

Modal yang dipakai untuk operasional dengan tujuan membangun perusahaan disebut dengan ekuitas.

3. Perolehan Akun dalam Penyusunan Laporan Keuangan

Laporan keuangan PT Cipta Agung Lestari yang disusun berdasarkan SAK ETAP diperoleh rincian akun-akun yang dimasukkan dalam laporan keuangan 31 Desember 2017 (dalam rupiah) adalah sebagai berikut:

\section{Kas dan Setara Kas}

Kas:

Kas Rupiah

78.503 .000

Kas USD

338.700 .000

Kas RMB

Jumlah Kas
Bank:

Bank Maybank

Bank BCA

Bank Mandiri

Deposito Bank CIMB Niaga

Jumlah Bank

Jumlah Kas dan Setara Kas

10.373 .839

1.983 .545 .792

564.352 .355

76.906 .291

100.000 .000

2.735 .178 .277

3.850 .855 .944

Piutang Usaha

Piutang Usaha

Jumlah Piutang Usaha

Piutang Lain-lain

Piutang Karyawan

Piutang Toko Cabang

Jumlah Piutang Lain-lain

Persediaan

Persediaan Barang Jadi

Persediaan Barang Dalam Perjalanan

Persediaan Barang Packing

Jumlah Persediaan

Beban Dibayar di Muka

Sewa Mall

Sewa Ruko

Jumlah Beban Dibayar di Muka

37.049 .348 .458

37.049.348.458

36.762 .500

18.000 .000

$\mathbf{5 4 . 7 6 2 . 5 0 0}$

Aset Tetap

Tanah

Bangunan

(Akm Penyusutan Bangunan)

Kendaraan

(Akm Penyusutan Kendaraan

Peralatan Kantor

(Akm Penyusutan Peralatan)

Jumlah Aset Tetap

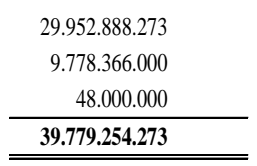

232.120 .350

139.583 .333

371.703.683

2.500 .000 .000

20.900 .122 .845

(7.676.059.995)

1.257.000.000

(969.604.167)

228.776 .550

(228.776.550)

16.011.458.683

Aset Lain-lain

Deposito Jaminan Bank CIMB Niaga

Jumlah Aset Lain-lain

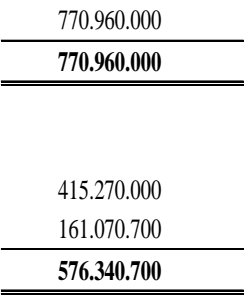

Hutang Dagang

Hutang PT Tixpro

Hutang PT Datascrip

Jumlah Hutang Dagang

1.115 .677 .667


Pendapatan

Penjualan

Pendapatan Jasa

Jumlah Pendapatan

Harga Pokok Penjualan

HPP

Jumlah HPP

Beban Usaha

Beban Umum dan Administrasi :

Beban Gaji Karyawan

Beban Sewa Gudang

Beban Maintenance

Beban Listrik dan PAM

Beban Telepon dan Internet

Beban Air Minum

Beban ATK

Beban Perlengkapan Kantor

Beban Transport

Beban Perawatan Kendaraan

Beban Perawatan Kantor

Beban Packaging Barang

Beban Kuli

Beban Ekspedisi

Beban Perizinan dan Legal

Beban Iuran dan Sumbangan

Beban Konsultan

Beban Iklan

Beban Entertaintment

Beban Perjalanan Dinas

Beban Penyusutan Bangunan

Beban Penyusutan Kendaraan

Jumlah Beban Umum dan Administrasi

Beban Keuangan Bank :

Beban Administrasi Bank

Beban Bunga Bank

Beban Pajak Bunga

Jumlah Beban Keuangan Bank

Beban 0perasi Lain-lain :

\section{Beban Lain-lain}

Laba/rugi Stock Opname

Laba/rugi Penjualan Aktiva

Laba/rugi Selisih Kurs

Jumlah Beban Operasi Lain-lain
31.131.787

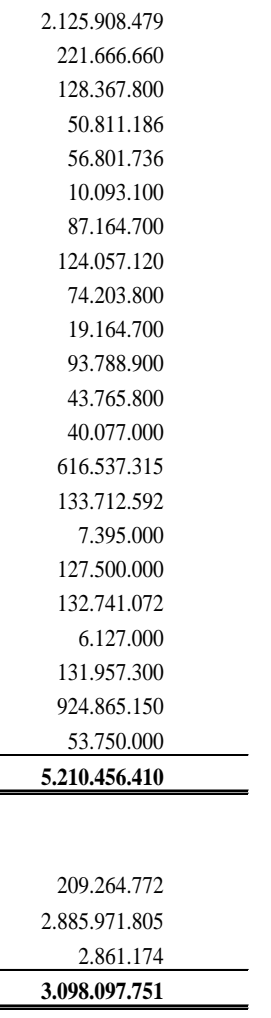

5.242 .890

3.680 .700

32.442 .592

72.497.969

Analisis penelitian penyusunan laporan keuangan PT Cipta Agung Lestari membahas mengenai kesesuaian dari laporan keuangan yang mengacu pada SAK ETAP. Berdasarkan hasil penelitian mengenai pembuatan laporan keuangan PT Cipta Agung Lestari sesuai SAK ETAP akan diuraikan sebagai berikut.

\section{Analisis Jurnal Penyesuaian PT Cipta Agung Lestari}

Analisis yang dilakukan pada beban perlengkapan, beban bunga bank, beban gaji, beban sewa dan beban penyusutan oleh PT Cipta Agung Lestari menurut hasil penelitian yang dilakukan peneliti ternyata PT Cipta Agung Lestari tidak menjalankan jurnal penyesuaian pada akun-akun yang seharusnya disesuaikan pada setiap akhir periode. Jurnaljurnal penyesuaian yang dilakukan pada setiap akhir periode untuk melakukan pencatatan yang aktual serta membandingkan beban dan pendapatan. Oleh karena itu, peneliti merekomendasikan jurnal-jurnal penyesuaian untuk PT Cipta Agung Lestari yaitu sebagai berikut:

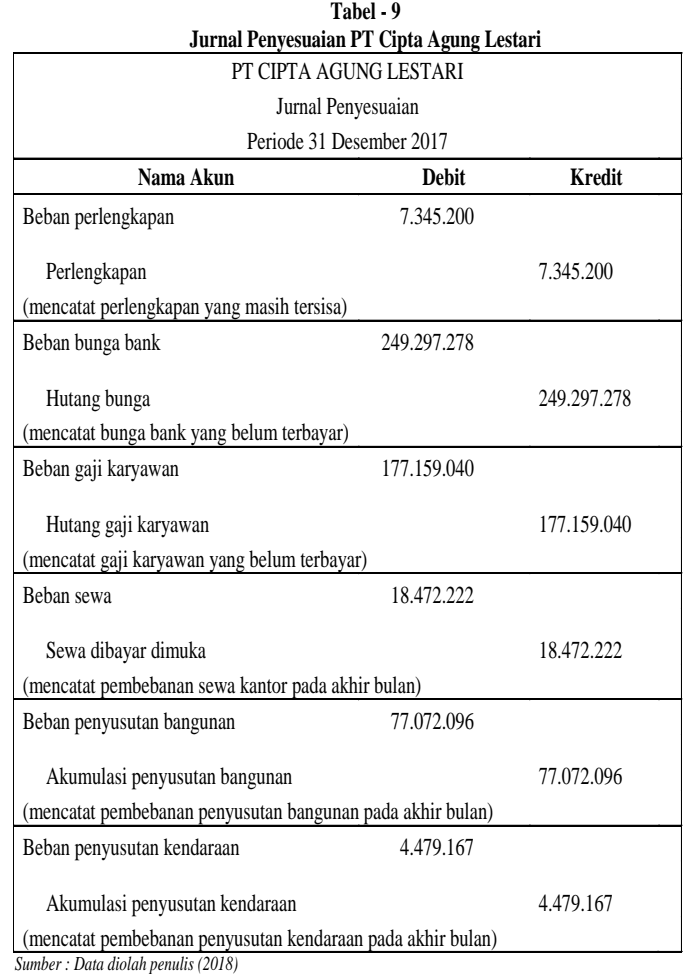

\section{Analisis Komponen Laporan Keuangan PT Cipta Agung Lestari dengan Laporan Keuangan Berdasarkan SAK ETAP}

Dari hasil penelitian terlihat adanya perbedaan antara laporan keuangan PT Cipta Agung Lestari dengan laporan keuangan yang mengacu pada SAK ETAP: 


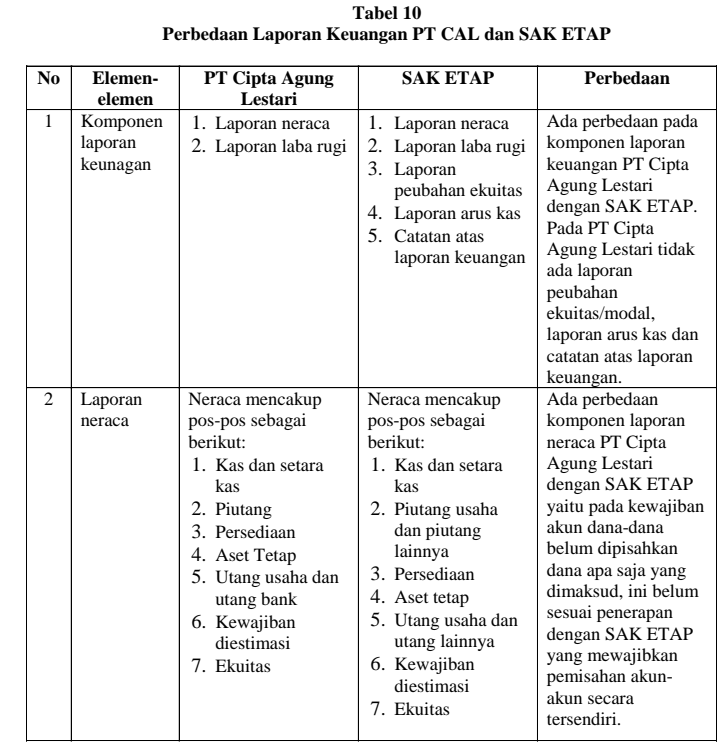

\begin{tabular}{|c|c|c|c|c|}
\hline 3 & $\begin{array}{l}\text { Laporan } \\
\text { laba rugi }\end{array}$ & $\begin{array}{l}\text { Laba rugi mencakup } \\
\text { pos-pos sebagai } \\
\text { berikut: } \\
\text { 1. Pendapatan } \\
\text { 2. Beban keuangan } \\
\text { 3. Laba atau rugi } \\
\text { neto }\end{array}$ & $\begin{array}{l}\text { Laba rugi mencakup } \\
\text { pos-pos sebagai } \\
\text { berikut: } \\
\text { 1. Pendapatan } \\
\text { 2. Beban keuangan } \\
\text { 3. Bagian laba atau } \\
\text { rugi dari investasi } \\
\text { yang } \\
\text { menggunakan } \\
\text { metode ekuitas } \\
\text { 4. Beban pajak } \\
\text { 5. Laba atau rugi } \\
\text { neto }\end{array}$ & $\begin{array}{l}\text { Terdapat perbedaan } \\
\text { dalam laporan laba } \\
\text { rugi pada PT Cipta } \\
\text { Agung Lestari yaitu } \\
\text { tidak terdapat beban } \\
\text { pajak yang } \\
\text { diwajibkan oleh SAK } \\
\text { ETAP. }\end{array}$ \\
\hline 4 & $\begin{array}{l}\text { Laporan } \\
\text { perubahan } \\
\text { ekuitas }\end{array}$ & $\begin{array}{l}\text { Tidak membuat } \\
\text { laporan perubahan } \\
\text { ekuitas }\end{array}$ & $\begin{array}{l}\text { Mencakuppos-pos } \\
\text { sebagai berikut: } \\
\text { 1. Modal awal } \\
\text { 2. Laba tahun } \\
\text { berjalan }\end{array}$ & $\begin{array}{l}\text { Ada perbedaan } \\
\text { karena PT Cipta } \\
\text { Agung Lestari tidak } \\
\text { membuat laporan } \\
\text { perubahan ekuitas } \\
\text { yang diwajibkan } \\
\text { SAK ETAP dan } \\
\text { belum sesuai dengan } \\
\text { SAK ETAP. }\end{array}$ \\
\hline 5 & $\begin{array}{l}\text { Laporan } \\
\text { arus kas }\end{array}$ & $\begin{array}{l}\text { Tidak membuat } \\
\text { laporan arus kas }\end{array}$ & $\begin{array}{l}\text { Mencakup pos-pos } \\
\text { sebagai berikut: } \\
\text { 1. Aktivitas operasi } \\
\text { 2. Aktivitas } \\
\text { investasi } \\
\text { 3. Aktivitas } \\
\text { pendanaan }\end{array}$ & $\begin{array}{l}\text { Ada perbedaan } \\
\text { karena PT Cipta } \\
\text { Agung Lestari tidak } \\
\text { membuat laporan } \\
\text { arus kas dan belum } \\
\text { sesuai dengan SAK } \\
\text { ETAP. }\end{array}$ \\
\hline 6 & $\begin{array}{l}\text { Catatan } \\
\text { atas laporan } \\
\text { keuangan }\end{array}$ & $\begin{array}{l}\text { Tidak membuat } \\
\text { catatan atas laporan } \\
\text { keuangan }\end{array}$ & $\begin{array}{l}\text { Catatan atas laporan } \\
\text { keuangan berisi } \\
\text { tentang gambaran } \\
\text { umum yang meliputi } \\
\text { pendirian, badan } \\
\text { hukum dan akun- } \\
\text { akun yang diperoleh } \\
\text { dari laporan } \\
\text { keuangan. }\end{array}$ & $\begin{array}{l}\text { Ada perbedaan } \\
\text { karena PT Cipta } \\
\text { Agung Lestari tidak } \\
\text { membuat catatan atas } \\
\text { laoran keuangan dan } \\
\text { juga belum sesuai } \\
\text { dengan SAK ETAP. }\end{array}$ \\
\hline
\end{tabular}

Tabel 10 memperlihatkan bahwa laporan keungan pada PT Cipta Agung Lestari, sebelum menyusun laporan keuangan berdasarkan SAK ETAP hanya terdiri dari laporan neraca (posisi keuangan) dan laporan laba rugi (sisa hasil usaha), meskipun hal tersebut sudah memberikan informasi kepada pihak-pihak terkait namun PT Cipta Agung Lestari perlu menyusun dan menyajikan laporan keuangan yang sesuai dengan SAK ETAP yang berupa laporan neraca (posisi keuangan), laporan laba rugi (sisa hasil usaha), laporan perubahan ekuitas, laporan arus kas dan catatan atas laporan keuangan. Pada laporan neraca masih harus diperbaiki dalam penyusunanya yaitu pada kewajiban jangka pendek seharusnya untuk pos hutang bank dimasukkan kedalam pos kewajiban jangka panjang dan hutang bunga bank dimasukkan kedalam pos hutang lain-lain. Hal ini dilakukan oleh pihak PT Cipta Agung Lestari karena kurangnya akuntan yang terlatih untuk mengetahui pencatatan yang sudah ditetapkan oleh SAK ETAP. Pada laporan laba rugi PT Cipta Agung Lestari tidak menghitung kewajiban pajak yang harus dibayarkan kepada pemerintah, SAK ETAP mengatur setiap perusahaan wajib mencantumkan perhitungan beban-beban pajak secara mandiri ini belum sesuai dengan laporan laba rugi yang dibuat oleh PT Cipta Agung Lestari. PT Cipta Agung Lestari tidak membuat laporan perubahan ekuitas, hal tersebut juga menunjukkan bahwa PT Cipta Agung Lestari belum sepenuhnya mengikuti SAK ETAP. Pada laporan perubahan ekuitas/modal penting dalam laporan keuangan untuk mengetahui modal akhir perusahaan. PT Cipta Agung Lestari tidak membuat laporan arus kas, ini dapat membuat kurangnya informasi dari mana perputaran penerimaan dan pengeluaran kas, tidak adanya laporan arus kas dapat menimbulkan fraud. PT Cipta Agung Lestari juga tidak membuat catatan atas laporan keuangan sebagai pelengkapnya laoran keuangan, maka belum sepenuhnya mengikuti SAK ETAP. Pembuatan laporan keuangan yang sudah sesuai SAK ETAP dimaksudkan untuk menjaga akuntabilitas keuangan yang tepat bagi PT Cipta Agung Lestari agar pemakai laporan keuangan dapat mengetahui dengan jelas bagaimana kondisi keuangan, untuk melihat sehat atau tidaknya perusahaan dan dapat mengembangkan serta meningkatkan kualitas dan kuantitas PT Cipta Agung Lestari.

\section{KESIMPULAN DAN SARAN Kesimpulan}

Berlandaskan pada hasil penelitian yang sudah dilakukan mengenai analisis penyajian dan penyusunan laporan keuangan yang berdasarkan pada SAK ETAP pada PT Cipta Agung Lestari diharapkan dapat memberikan informasi tambahan dan kontribusi tentang bagaimana tahapan menyusun laporan keuangan yang sesuai dengan SAK ETAP, 
berikut adalah kesimpulan yang dapat ditarik, sebagai berikut:

1. PT Cipta Agung Lestari belum menyusun laporan keuangan secara lengkap yang mengacu pada SAK ETAP, hanya terdiri dari laporan neraca (posisi keuangan) dan laporan laba rugi (sisa hasil usaha).

2. Penyajian laporan keuangan PT Cipta Agung Lestari belum sesuai dengan SAK ETAP karena belum menerapkan jurnal penyesuaian dalam siklus akuntansinya serta tidak adanya laporan perubahan ekuitas, laporan arus kas serta catatan atas laporan keuangan. Pada laporan neraca (posisi keuangan) sudah mengacu pada SAK ETAP hanya saja belum sesuai dengan pos-pos akun pada SAK ETAP dan pada laporan laba rugi belum memasukkan beban pajak yang seharusnya dibayarkan perusahaan kepada Negara dan pada pos-pos pendapatan dan beban belum sepenuhnya sesuai dengan SAK ETAP.

3. Kendala Penyusunan Laporan Keuangan Kendala yang dihadapi oleh PT Cipta Agung Lestari pada proses penelitian ini berlangsung adalah:

a) Adanya kekurangan sumber daya manusia dalam perekrutan karyawan pada PT Cipta Agung Lestari, seacra kuantitas maupun kualitas. Dilihat dari segi kuantitas, karyawan PT Cipta Agung Lestari yang merupakan lulusan dari bidang ekonomi yaitu akuntansi sangatlah sedikit, hal ini dapat dilihat dari penyusunan laporan keuangan hanya dibuat oleh satu orang saja dan itupun juga merangkap pekerjaan sebagai personal assistant, hal tersebut seharusnya dilakukan pemisahan tugas. Sedangkan dari segi kualitas, adanya karyawan yang sudah cukup mengerti dan paham mengenai dasar-dasar akuntansi tetapi belum sepenuhnya menguasai hal-hal yang lebih rinci menngenai penyusunan laporan keuanagn yang berdasarkan pada SAK ETAP, maka dari itu PT Cipta Agung Lestari memerlukan transfer knowledge untuk dapat lebih memahami tentang cara-cara atau ilmu-ilmu untuk menyusun dan menyajikan laoran keuangan agar sesuai dengan standar yang berlaku. b) Masih bercampurnya rekening perusahaan dan rekening pribadi pemilik, sehingga sulit menentukan aktivitas keuangan untuk operasional perusahaan dan untuk pribadi.

c) Kurangnya kesadaran pihak PT Cipta Agung Lestari akan pentingnya laporan keuangan yang sesuai dengan standar akuntansi yang berlaku di Indonesia pada saat ini. Karena laporan keuangan sangat dibutuhkan dalam pengajuan kredit bank untuk penambahan modal perusahaan.

\section{Saran}

Berdasarkan pada hasil analisa dan kesimpulan pada penilitian ini, maka saran yang diberikan untuk mengharapkan dapat memberikan kontribusi dan dampak positif untuk di masa mendatang bagi PT Cipta Agung Lestari adalah:

1. PT Cipta Agung Lestari sebaiknya merekrut dan mempekerjakan karyawan yang ahli atau menguasai bidang akuntansi agar dapat menyusun laporan keuangan yang sesuai dengan standar keaunagan yang berlaku serta dilakukan secara berkelanjutan dan dan bijaksana dalam hal pembagian tugas berdasarkan kedudukannya dalam bekerja agar bisa meminimalisir adanya pekerjaan yang merangkap.

2. Untuk memudahkan penyusunan dan penyajian laoran keuangan berdasarkan SAK ETAP, perusahaan sebaiknya melakukan siklus akuntansi yang benar dan lengkap yaitu berdasarkan transaksi, kemudian dibuat jurnal umumnya, kemudian menyusun dan memasukkan ke dalam buku besar, lalu ke neraca saldo, melakukan jurnal penyesuaian, kemudian neraca saldo setelah dilakukannya penyeseuaian, kemudian melakukan jurnal penutup, neraca saldo setelah penutupan dan yang terakhir adalah membuat laporan keuangan. Hal tersebut untuk memudahkan perusahaan dalam melakukan penyusunan laporan keuangan secara lengkap pada akhir periode berdasarkan SAK ETAP.

3. Sebaiknya PT Cipta Agung Lestari menambah tingkat kesadaran pada pentingnya laporan keuangan karena berfungsi sebagai gambaran perbandingan kinerja perusahaan diperiode sekarang dan diperiode mendatang. 


\section{DAFTAR PUSTAKA}

Agoes, Sukrisno dan Estralita, Trisnawati, 2014, Akuntansi Perpajakan Edisi 3, Jakarta: Salemba Empat.

Ahmed, Riahi Belkaoui, 2011, Accounting theory, Buku Jilid 2, Jakarta: Salemba Empat.

Cahyono, A. T. 2011, Meta Teori Standar Akuntansi Keuangan di IndonesiaMenuju Konvergensi SAK di Masa Globalisasi. Jurnal Eksis. 7: 2.

Cahyono, Nur dan Dwi R. 2012, Adopsi IFRS dan Relevansi Nilai Informasi Akuntansi, Fakultas Ekonomika dan Bisnis Universitas Diponegoro, Jurnal Akuntansi dan Keuangan, Vol. 14, No. 2, November 2012: 105-115.

Dina Fitria. 2014, Buku Pintar Akuntansi Untuk Orang Awam \& Pemula, Jakarta Timur: Laskar Aksara.

Dwi Martani, 2012, Akuntansi Keuangan Menengah Berbasis PSAK, Jakarta: Salemba Empat

FannyHarfiani, 2012, Contoh Membuat Akuntansi Excel, Jakarta: Agromedia Pustaka

Hanafi, M Mamduh, 2016, Analisis Laporan Keuangan, Edisi Keempat. Yogyakarta: UPP STIM YKPN.

Harahap,S.S,2015, Analisis Kritis atas Laporan Keuangan, Jakarta: PT Raja Grafindo Persada.
Herry, S.E, M.Si, 2012, Memahami Laporan Keuangan, Jakarta: PT Bumi Aksara.

Hery, 2014, Akuntansi Dasar 1 dan 2, Jakarta: Grasindo.

Ikatan Akuntan Indonesia, 2016, Standar Akuntansi Keuangan Entitas Tanpa Akuntabilitas Publik (SAK-ETAP), Jakarta: IAI.

Indriantoro, Nur dan Supomo, 2014, Metodologi Penelitian Bisnis untuk Akuntansi \& Manajemen, Yogyakarta: BPFE.

Ismail Razak, Achmad Junaedi, Lukman Hakim, 2012, Metodologi Penelitian Ekonomi \& Bisnis, Jakarta: Prenada.

Kasmir. 2016, Analisis Laporan Keuangan. Jakarta: PT Rajawali Persada

Puspitawati Lilis, Sri Dewi Anggadini, 2011, Sistem Informasi Akuntansi, Yogyakarta: Graha ilmu.

Rahman Pura, 2013, Pengantar Akuntansi 1 : Pendekatan Siklus Akuntansi, Makasar: Erlangga.

Rudianto, 2014, Pengantar Akuntansi Konsep dan Teknik Penyusunan Laporan Keuangan. Jakarta: Salemba Empat

Sugiyono, 2014, Metode Penelitian Kuantitatif, Kualitatif, dan $R \& D$, Bandung: Penerbit Alfabeta. 
